\title{
PENGARUH EKSTRAK TANAMAN PUTRI MALU (Mimosa pudica Linn) TERHADAP PENURUNAN KADAR GLUKOSA DARAH PADA MENCIT (Mus musculus)
}

\author{
The Effect of Mimosa Plant Extract (Mimosa pudica Linn) on Decreasing of \\ Blood Sugar Levels on Mice (Mus musculus)
}

\author{
*Kasmudin Mustapa, Amalia Rizky dan Minarni Rama Jura dan \\ Pendidikan Kimia/FKIP - Universitas Tadulako, Palu - Indonesia 94118 \\ Recieved 05 December 2016, Revised 03 January 2017, Accepted 06 February 2017
}

\begin{abstract}
The research aim is to determine the effect of mimosa plant (Mimosa pudica Linn) to reduce blood sugar levels in mice and determining the effective concentration of mimosa plant extracts as an alternative to decrease blood sugar levels. Extract is produced by the infusion method. The animal test used is male mice with amount 18 mice that induced by EDTA (Ethylene Diamine Tetraacetic Acid). Mice are divided into 6 groups randomly with different treatment. The group I, II, III and IV are respectivelygiven the mimosa plant extract with a concentration of 10\% (w/v), 20\% (w/v), 30\% (w/v), and $40 \%(w / v)$ while group $V$ is given glibenclamide suspension as positive control $(+)$ and group $V I$ is given Na-CMC $1 \%$ as negative control (-). Data areanalyzed using the statistical test analysis of variance (ANOVA) and then followed by Duncan test. The results showed that the mimosa plant extract contains flavonoids, alkaloids, and tannins. In preclinical testing of mimosa plant extract proven to reduce blood sugar levels in mice and the most effective concentration is concentration of $20 \%(\mathrm{w} / \mathrm{v})$ with significantly $\alpha=0.05$
\end{abstract}

Keywords: mimosa plant, diabetes mellitus, blood glucose levels, antidiabetic

\section{Pendahuluan}

Diabetes Melitus merupakan masalah kesehatan yang menghinggapi hampir seluruh masyarakat dunia. Di negara maju, diabetes merupakan masalah utama sedangkan di negara berkembang penyakit menular dan kurang pangan masih menjadi masalah utama kesehatan (Ranakusuma, 1987). Diabetes Mellitus merupakan keadaan ketiadaan atau kekurangan penghasil insulin, atau badan bersifat rentan terhadap insulin. Diabetes Mellitus merupakan penyakit kronik yang akan kekal seumur hidup. Selain jumlah penderita yang terus meningkat, hal lain yang perlu diwaspadai dari Diabetes Mellitus adalah bahaya komplikasi yang timbul jika Diabetes Mellitus tidak terkendali. Penderita Diabetes Mellitus tetap dapat hidup normal dan berkualitas dengan cara mengendalikan kadar gula darahnya mendekati nilai normal. Komplikasi Diabetes

*Correspondence:

Kasmudin Mustapa

Program Studi Pendidikan Kimia, Fakultas Keguruan dan Ilmu Pendidikan, Universitas Tadulako

email: mumutep@gmail.com

Published by Universitas Tadulako 2017
Mellitus dapat dicegah, pengendalian Diabetes Mellitus yang baik sangat diperlukan untuk meningkatkan kualitas hidup penderita dan mencegah timbulnya komplikasi di kemudian hari (Kirwanto, 2014).

Obat-obat antidiabetik yang ada saat ini, meskipun memberikan kontribusi besar dalam menurunkan diabetes, tetapi masih memiliki banyak keterbatasan terutama efek samping yang ditimbulkan seperti hipoglikemia, peningkatan berat badan dan ketidakmampuan untuk mencegah degenerasi pankreas atau komplikasi diabetik yang berhubungan dengan stres oksidatif (Novrial, dkk., 2012). Obat tradisional dari tumbuhan dapat menjadi salah satu alternatif pengobatan apalagi di tengah situasi perekonomian dimana salah satu konsekuensinya adalah tingginya harga obat sintetik. Meskipun banyak senyawa kimia organiksintetik telah tersedia untuk penggunaan pengobatan berbagai penyakit, tetapi sangatlah penting untuk mencari alternatif obat baru yang memungkinkan efektivitas pengobatan yang lebih baik dan diharapkan mempunyai 
efek samping minimal, salah satunya obat yang diekstrak dari tumbuhan (Nurulita, dkk., 2008). Manfaat penggunaan obat tersebut sangat besar, dengan keadaan ekonomi masyarakat, dimana penggunaan obat tradisional ini akan menghemat biaya kehidupan (Nursyiah, 2013). Pengobatan secara tradisional sebagian besar menggunakan ramuan yang berasal dari tumbuh-tumbuhan baik berupa akar, batang, biji, bunga, daun, ataupun kulit kayu. Bagianbagian dari tumbuhan tersebut mengandung senyawa metabolit sekunder yang terdiri dari empat golongan utama, yaitu steroid, flavonoid, alkaloid, dan terpenoid. Senyawa metabolit sekunder tersebut memiliki aktivitas biologis. Salah satu di antaranya dapat mengobati penyakit diabetes mellitus (Sukandar, dkk., 2012) .

Menurut Purwatresna (2012) senyawa yang memiliki aktivitas antidiabetes adalah flavanoid, alkaloid, dan tannin, sedangkan hasil penelitian yang dilakukan Putri (2013) yaitu analisis kualitatif zat bioaktif daun alpukat (Persea Americana Mill.) dan uji praklinis dalam menurunkan kadar glukosa darah pada mencit menyatakan bahwa senyawa yang paling efektif menurunkan gula darah adalah senyawa alkaloid dan flavanoid. Salah satu tanaman yang dapat dijadikan alternatif obat herbal adalah putri malu (Mimosa pudica Linn), tanaman ini mengandung senyawa mimosin, asam pipekolinat, tannin, alkaloid, saponin, triterpenoid, sterol, polifenol dan flavonoid yang diduga berperan dalam menurunkan kadar glukosa darah pada penderita Diabetes Mellitus (Setiawati, dkk., 2008).

Menurut Azmi, dkk., (2011) tanaman putri malu memiliki aktivitas famakologis seperti antidiabetes, antitoksin, antihepatotoxin, penyembuhan antioksidan dan luka. Di Sulawesi Tengah, tanaman putri malu (Mimosa pudica Linn) mudah ditemukan, dan tanaman ini hidup liar namun pemanfaatan sebagai obat tradisional kurang dimanfaatkan secara maksimal. Tulisan ini dimaksudkan untuk memberikan gambaran mengenai ekstrak tanaman putri malu (Mimosa pudica Linn) yang dapat menurunkan kadar gula darah pada mencit (Mus musculus) dan konsentrasi ekstrak tanaman putri malu (Mimosa pudica Linn) yang efektif menurunkan kadar gula darah pada mencit (Mus musculus).

\section{Metode}

\section{Alat dan Bahan}

Alat yang digunakan adalah gelas ukur, gelas kimia, labu ukur, corong, pissau/cutter, spatula, corong, batang pengaduk, penangas listrik, spatula, lumpang dan alu, kain flannel, kertas label, kertas saring, kapas, pipet tetes, tabung reaksi, rak tabung, blender, gegep, thermometer, glukometer, strip gluco Dr, spoit, neraca digital, suntik sonde, gunting, sarung tangan, kandang hewan, timbangan hewan. Bahan-bahan yang digunakan yaitu tanaman putri malu, hewan uji (mencit), EDTA (Merck), Na-CMC (Merck), glibenklamid, glukosa 10\% (Merck KGaA), aquades, Reagen Dragendroff, etanol (Merck KGaA), $\mathrm{HCl}$ pekat (Merck $K G a A), \mathrm{FeCl}_{3} 1 \%($ Merck $K G a A)$, logam $\mathrm{Mg}$, alkohol $70 \%$.

\section{Cara Kerja}

Pembuatan Ekstrak Tanaman Putri Malu

Ekstrak putri malu dibuat dengan metode infusa. Serbuk tanaman putri malu yang telah kering ditimbang sebanyak 10 gram. Kemudian dimasukkan ke dalam erlenmeyer dan ditambahkan dengan aquades sebanyak $100 \mathrm{~mL}$. Erlenmeyer tersebut dimasukan ke dalam gelas kimia $1000 \mathrm{~mL}$ yang telah berisikan air dan dipanaskan pada suhu $90^{\circ} \mathrm{C}$ selama 15 menit. Kemudian disaring dalam keadaan panas menggunakan kain flannel dan jika volume kurang dari $100 \mathrm{~mL}$, maka ditambahkan dengan air hangat melalui residu saringan hingga volumenya mencapai 100 mL. Ekstrak putri malu 20\%, 30\% dan 40\% dibuat dengan cara yang sama, menggunakan 20 gram, 30 gram dan 40 gram serbuk tanaman putri malu.

\section{Pengujian Flavonoid}

Sampel sebanyak 0,5 gram ditimbang selanjutnya ditambahkan $5 \mathrm{~mL}$ aquades dan dipanaskan kemudian disaring. Filtrat ditambahkann dengan 0,1 gram logam $\mathrm{Mg}$ dan 5 tetes $\mathrm{HCl}$ pekat. Apabila menghasilkan warna kuning jingga maka hasilnya positif mengandung flavonoid.

\section{Pengujian Alkaloid}

Sampel sebanyak 0,5 gram ditimbang selanjutnya ditambahkan $5 \mathrm{~mL}$ aquades dan dipanaskan kemudian disaring. Selanjutnya 
filtrat ditambahkan dengan 5 tetes $\mathrm{HCl}$ pekat dan 5 tetes reagen Dragendroff. Apabila menghasilkan endapan yang berwarna jingga maka hasilnya positif mengandung alkaloid.

Pengujian Tanin

Sampel sebanyak 0,5 gram ditimbang selanjutnya ditambahkan $5 \mathrm{~mL}$ aquades dan dipanaskan kemudian disaring. Selanjutnya filtrat ditambahkan dengan 5 tetes $\mathrm{FeCl}_{3} 1 \%$. Jika positif tanin jika terbentuk warna hijau kehitaman

\section{Pembuatan Koloid Na-CMC 1\% b/v}

Koloid $\mathrm{Na}-\mathrm{CMC} 1 \%$ dibuat dengan melarutkan 1 gram $\mathrm{Na}-\mathrm{CMC}$ sedikit demi sedikit ke dalam $50 \mathrm{~mL}$ air suling panas sambil diaduk hingga terbentuk koloid. Volume dicukupkan hingga $100 \mathrm{~mL}$ dengan air suling.

\section{Pembuatan Suspensi Glibenklamid}

1 tablet glibenklamid $5 \mathrm{mg}$, digerus dengan lumpang setelah itu ditambahkan dengan koloid $\mathrm{Na}$-CMC 1\% b/v sedikit demi sedikit sambil diaduk hingga homogen. Masukkan dalam labu ukur $100 \mathrm{~mL}$ kemudian cukupkan hingga volumenya $100 \mathrm{~mL}$ dengan koloid $\mathrm{Na}$ CMC $1 \%$.

\section{Pemilihan dan Penyiapan Hewan Uji}

Hewan uji yang digunakan adalah mencit (Mus musculus) jantan berbadan sehat, berumur 2-3 bulan dengan berat badan berkisar antara 20 gram sampai 30 gram. Mencit yang digunakan sebanyak 18 ekor dan dibagi dalam 6 kelompok perlakuan.

\section{Perlakuan Terhadap Hewan Uji}

Sebelum diberikan perlakuan hewan uji dipuasakan selama 16 jam. Kemudian diukur kadar glukosa darahnya. Setelah itu, semua hewan dikelompok dan diinduksikan secara intervena dengan EDTA dengan dosis 150 $\mathrm{mg} / \mathrm{kg}$ BB. Kemudian diberi glukosa $10 \%$ dan selama perlakuan mencit tetap diberi pakan. Setelah 3 hari, kadar glukosa darah kembali diukur untuk memastikan kadar EDTA masih berfungsi sebagai diabetik eksperimental. Mencit dikelompokkan menjadi 6 kelompok dan diberi perlakuan yaitu :

P1: perlakuan 1 (pakan + EDTA + glukosa $10 \%+$ ekstrak tanaman putri malu $10 \%+$ Na-CMC 1\%); P2: perlakuan 2 (pakan +
EDTA + glukosa $10 \%$ + ekstrak tanaman putri malu 20\% + Na-CMC 1\%); P3: perlakuan 3 (pakan + EDTA + glukosa 10\% + ekstrak tanaman putri malu 30\% + Na-CMC 1\%); P4: perlakuan 3 (pakan + EDTA + glukosa 10\% + ekstrak tanaman putri malu $40 \%+\mathrm{Na}-\mathrm{CMC}$ 1\%); P5: perlakuan 4 kontrol positif (pakan + EDTA + glukosa $10 \%$ + glibenklimid + NaCMC 1\%); P6: perlakuan 5 kontrol negatif (pakan + EDTA + glukosa 10\% + Na-CMC $1 \%$.

Selesai perlakuan mencit diistirahatkan di dalam kandangnya masing-masing dan diberikan makanan dan minuman seperti biasanya. Kadar glukosa darah diukur kembali pada hari ke 1,4 dan 7 yaitu pengukuran gula darah akhir.

\section{Penentuan Kadar Glukosa Darah}

Sebelum digunakan, glukometer dihidupkan dan strip glukosa dimasukkan ke dalam glukometer. Darah diambil melalui ekor hewan uji (mencit) kemudian diteteskan pada strip glukometer. Dalam waktu 10 detik kadar glukosa darah akan terukur secara otomatis dan hasilnya dapat dibaca pada monitor glukometer. Setelah hasil data glukosa darah awal diperoleh yang meliputi, glukosa darah setelah induksi, glukosa darah setelah perlakuan, dan penurunan glukosa dari keenam perlakuan tersebut selanjutnya dianalisis dan dievaluasi dengan menggunakan rancangan acak kelompok melalui uji statistik analisis sidik ragam (uji F) dengan taraf kepercayaan 95\%. Uji ini digunakan untuk mengetahui perbedaan yang signifikan dari semua perlakuan, dan jika terdapat perbedaan maka pengujian dilanjutkan dengan uji Duncan untuk mengetahui perlakuan mana yang mempunyai perbedaan yang nyata.

\section{Hasil dan Pembahasan}

Uji Senyawa Metabolit Sekunder Ekstrak Tanaman Putri Malu (Mimosa pudica Linn)

Hasil pengamatan kualitatif senyawa metabolit sekunder ekstrak tanaman putri malu (Mimosa pudica Linn) dapat dilihat pada Tabel 1.

Hasil uji senyawa metabolit sekunder yang terkandung dalam ekstrak tanaman putri malu dapat dilihat pada Tabel 1 diatas dapat diketahui bahwa ekstrak tanaman putri malu positif mengandung senyawa flavanoid, 
Tabel 1. Hasil Uji Senyawa Metabolit Sekunder Ekstrak Tanaman Putri Malu

\begin{tabular}{|c|c|c|c|}
\hline No & Perlakuan & Hasil Pengamatan & Keterangan \\
\hline 1. & $\begin{array}{l}\text { Uji Flavanoid } \\
0,5 \text { gram sampel }+5 \mathrm{~mL} \text { aquades } \\
+ \text { dipanaskan }+ \text { disaring } \\
\text { Fitrat }+0,1 \mathrm{~g} \text { logam } \mathrm{Mg}+5 \text { tetes } \\
\mathrm{HCl} \text { pekat }+ \text { dipanaskan } \\
\text { Jika terbentuk warna kuning } \\
\text { jingga maka bereaksi positif. }\end{array}$ & $\begin{array}{l}\text { Menghasilkan } \\
\text { larutan berwarna } \\
\text { kuning jingga }\end{array}$ & $(+++)$ \\
\hline 2. & $\begin{array}{l}\text { Uji Alkaloid } \\
0,5 \text { gram sampel }+5 \mathrm{~mL} \text { aquades } \\
+ \text { dipanaskan }+ \text { disaring } \\
\text { Fitrat }+5 \text { tetes } \mathrm{HCl} \text { pekat }+5 \\
\text { tetes reagen dragendroff }\end{array}$ & $\begin{array}{l}\text { Menghasilkan } \\
\text { endapan berwarna } \\
\text { jingga }\end{array}$ & $(++)$ \\
\hline 3. & $\begin{array}{l}\text { Uji Tanin } \\
0,5 \text { gram sampel }+5 \mathrm{~mL} \text { aquades } \\
+ \text { dipanaskan }+ \text { disaring } \\
\text { Fitrat }+1 \mathrm{~mL} \mathrm{FeCl} 3 \text { dipanaskan } \\
\text { Jika terbentuk warna hijau } \\
\text { kehitaman positif. }\end{array}$ & $\begin{array}{l}\text { Larutan berwarna } \\
\text { Hijau kehitaman }\end{array}$ & $(+++)$ \\
\hline
\end{tabular}

Keterangan : Hasil negatif $=(-)$; Hasil positif lemah $=(+)$; Hasil positif kuat $=$ $(++)$; Hasil positif sangat kuat $=(+++)$.

alkaloid, dan tanin. Flavonoid dapat mencegah komplikasi atau progresifitas diabetes mellitus dengan cara membersihkan radikal bebas yang berlebihan, memutuskan rantai reaksi radikal bebas, mengikat ion logam (chelating) dan memblokade jalur poliol dengan menghambat enzimaldosereduktase(Taufiqurrohman,2015). Flavonoid, terutama quercetin telah dilaporkan memiliki aktivitas antidiabetes (Hussain \& Marouf, 2013). Hill \& Howel (1985) dalam Arjadi \& Susatyo (2010) menyatakan bahwa quercetin dapat meningkatkan pengeluaran insulin dari sel pulau Langerhans melalui perubahan metabolisme $\mathrm{Ca}^{2+}$. Flavonoid terbukti mampu merangsang sistem kekebalan tubuh karena karakter antioksidan flavonoid yang dapat memulihkan sel beta-pankreas kerusakan yang disebabkan oleh aloksan. Komponen glikosidik flavonoid terjadi sebagai penekan dari radikal hidroksil, dan karena itu, mampu memblokir perkembangan diabetes. Flavonoid bisa berinteraksi dengan beberapa transporter protein maka akan menonaktifkan beberapa enzim dan konsentrasi menyebabkan hormon dalam jaringan. Quercetin mampu untuk memblokir pembentukan radikal bebas dan karena itu, dapat digunakan sebagai antidiabetes (Winarsi, dkk., 2014). Alkaloid menurunkan glukosa darah dengan cara menghambat absorbsi glukosa di usus, meningkatkan transportasi glukosa di dalam darah, merangsang sintesis glikogen dan menghambat sintesis glukosa dengan cara menghambatenzim glukosa 6-fosfatase, fruktosa 1,6-bifosfatase, serta meningkatkan oksidasi glukosa melalui glukosa 6-fosfatdehidrogenase. Glukosa 6-fosfatase dan fruktosa 1,6 bifosfatase merupakan enzim yang berperan dalam glukoneogenesis. Penghambatan pada kedua enzim ini akan menurunkan pembentukan glukosa dari substrat lain selain karbohidrat (Fauziah, dkk., 2014). Alkaloid mempunyai kemampuan regenerasi sel $\beta$ pankreas yang rusak. Peningkatan sekresi insulin diakibatkan oleh adanya efek perangsang saraf simpatis dari alkaloid yang berefek meningkatkan sekresi insulin (Arjadi \& Susatyo, 2010).

Tanin diketahui dapat memacu metabolisme glukosa dan lemak sehingga timbunan kedua sumber kalori ini dalam darah dapat dihindari. Tanin mempunyai aktivitas antioksidan dan aktivitas hipoglikemik yaitu dengan meningkatkan glikogenesis. Selain itu, tanin juga berfungsi sebagai astringent atau pengkhelat yang dapat mengerutkan membran epitel usus halus sehingga mengurangi penyerapan sari makanan dan sebagai akibatnya menghambat asupan gula dan laju peningkatan gula darah tidak terlalu tinggi (Taufiqurrohman, 2015).

\section{Pengaruh Konsentrasi Ekstrak Tanaman Putri Malu (Mimosa Pudica Linn) Terhadap Penurunan Glukosa Darah}

Ekstrak tanaman putri malu (Mimosa Pudica Linn) dalam penelitian ini diberikan pada mencit jantan yang berumur 2-3 bulan dengan berat badan bervariasi antara 20-30 gram. Pemilihan mencit sebagai hewan uji karena ketersediaannya yang cukup tinggi dan cukup peka untuk mewakili manusia dalam penentuan kadar glukosa darah. Mencit memiliki sistem metabolisme dan sistem pencernaan yang relatif sama dengan manusia (Salam, 2011).

Mencit terlebih dahulu dipuasakan selama 16 jam sebelum diberikan perlakuaan. Tujuannya yaitu untuk meminimalkan faktor makanan yang dapat mempengaruhi kadar gula darah pada mencit. Setelah dipuasakan, mencit tersebut diukur kadar glukosa darah awalnya dengan menggunakan alat glukometer. Selanjutnya hewan uji diinduksi dengan menggunakan EDTA (Ethylene Diamine Tetraacetic Acid). Fungsi dari larutan EDTA ini adalah untuk menghasilkan kondisi diabetik eksperimental (hiperglikemik) yang 
menimbulkan hiperglikemia dalam waktu dua sampai tiga hari. Pemberian EDTA dapat merusak substansi esensial didalam sel betapankreas sehingga menyebabkan berkurangnya insulin didalam sel beta-pankreas (Radiansah, 2013)

Pengukuran kadar glukosa darah mencit yang telah diinduksi dengan EDTA dilakukan pada hari ke-4, 7, dan 10. Penentuan hari dihitung sejak pemberian diabetogen (EDTA) pertama kali, hari ke-1 adalah hari pemberian EDTA. Kadar glukosa darah hewan uji setelah diinduksi EDTA harus lebih dari $120 \mathrm{mg} / \mathrm{dL}$. Syarat untuk terjadinya keadaan hiperglikemia pada hewan uji adalah ketika kadar glukosa darah hewan uji mencapai $>120 \mathrm{mg} / \mathrm{dL}$, oleh karena itu hewan uji diinduksi pada hari 1 , 4, dan 7. Pada hari ke-4 dan ke-7 dilakukan pengukuran kadar glukosa darah pada mencit telah mengalami kenaikan, namun kenaikannya tidak dapat memicu terjadinya diabetes, maka dilakukan induksi kembali pada hari itu juga. Selanjutnya hari ke-10 dilakukan pengukuran kadar glukosa darah pada mencit mengalami kenaikan yang telah menunjukan kondisi hiperglikemia (diabetes). Perlakuan selanjutnya adalah pemberian ekstrak tanaman putri malu (Evasuciany, dkk., 2010)

Hasil rerata kadar glukosa darah awal, setelah induksi, setelah diberikan perlakuan dan penurunan glukosa darah setelah diberikan ekstrak tanaman putri malu (Mimosa pudica Linn) dapat dilihat pada Tabel 2.

Tabel 2. Rarata Kadar Gula Darah Awal, Setelah Induksi, Setelah diberikan Perlakuan dan Penurunan Glukosa Darah Setelah Pemberian Ekstrak Tanaman Putri Malu (Mimosa pudica Linn.)

\begin{tabular}{ccccc}
\hline Perlakuan & $\begin{array}{c}\text { Glukosa darah } \\
\text { awal } \\
(\mathrm{mg} / \mathrm{dL})\end{array}$ & $\begin{array}{c}\text { Glukosa darah } \\
\text { setelah } \\
\text { induksi } \\
(\mathrm{mg} / \mathrm{dL})\end{array}$ & $\begin{array}{c}\text { Glukosa darah } \\
\text { setelah } \\
\text { perlakuan } \\
(\mathrm{mg} / \mathrm{dL})\end{array}$ & $\begin{array}{c}\text { Penurunan } \\
\text { glukosa darah } \\
(\mathrm{mg} / \mathrm{dL})\end{array}$ \\
\hline P1 & 71,00 & 143,66 & 112,00 & 31,66 \\
P2 & 77,33 & 140,33 & 85,00 & 55,33 \\
P3 & 73,66 & 147,66 & 87,66 & 60,00 \\
P4 & 68,66 & 144,00 & 117,33 & 24,33 \\
P5 & 72.33 & 143,00 & 85,00 & 58,00 \\
P6 & 73,00 & 145,00 & 133,00 & 12,00 \\
\hline
\end{tabular}

Keterangan : P1 : pakan + EDTA + glukosa $10 \%+$ ekstrak tanaman putri malu $10 \%+\mathrm{Na}-$ CMC; P2 : pakan + EDTA + glukosa 10\%
+ ekstrak tanaman putri malu $20 \%+\mathrm{Na}-$ CMC; P3 : pakan + EDTA + glukosa 10\% + ekstrak tanaman putri malu $30 \%+\mathrm{Na}-\mathrm{CMC}$; P4 : pakan + EDTA + glukosa 10\% + ekstrak tanaman putri malu 40\% + Na-CMC; P5 : pakan + EDTA + glukosa 10\% + glibenklimid $+\mathrm{Na}-\mathrm{CMC}$; P6 : pakan + EDTA + glukosa $10 \%+\mathrm{Na}-\mathrm{CMC}$.

Hasil pada Tabel 2 menunjukan bahwa rerata glukosa darah normal mencit berkisar 68,66$77,33 \mathrm{mg} / \mathrm{dl}$, setelah diinduksi EDTA berkisar 140-147 mg/dL. Dari hasil Homogenitas kadar gula darah mencit setelah induksi EDTA pada mencit menunjukkan tidak ada perbedaan yang signifikan antar kelompok perlakuan ( $p>0,05$ atau nilai signifikan 0,061>0,05). Dengan demikan, semua kelompok perlakuan layak dibandingkan karena tidak ada perbedaan yang signifikan. Untuk mengetahui seberapa besar penurunan glukosa darah pada mencit maka dilakukan perhitungan selisih antara kadar glukosa darah setelah diinduksi dengan kadar glukosa darah setelah pemberian ekstrak tanaman putri malu (Mimosa Pudica Linn). Hasil penurunan kadar glukosa darah, dapat dilakukan melalui perhitungan dari kadar glukosa darah setelah diinduksi EDTA dikurangi dengan kadar glukosa darah setelah perlakuan.Kemudian dihitung reratanya seperti yang terlihat pada Tabel 2. Adapun grafik yang memperlihatkan penurunan glukosa darah pada mencit terlihat pada Gambar 1.

Pada Gambar 1 terlihat bahwa rerata glukosa darah tersebut berbeda nyata antara beberapa perlakuan. Perlakuan yang paling berbeda nyata terlihat pada P1, P2, P3, P4, 


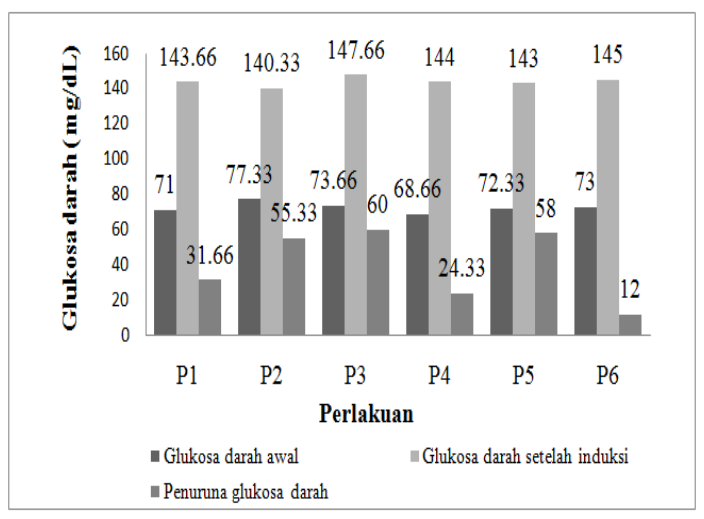

Gambar 1. Rerata Kadar Glukosa Darah Awal, Setelah Induksi dengan EDTA dan Penurunan Glukosa Darah

dan P5 dengan P6 yang menunjukan bahwa P1 untuk ekstrak tanaman putri malu 10\%, P2 ekstrak tanaman putri malu 20\%, P3 ekstrak tanaman putri malu 30\%, P4 ekstrak tanaman putri malu 40\% ekstrak, P5 pemberian obat glibenklamid (kontrol positif) berbeda menurunkan glukosa darah pada mencit dengan P6 (kontrol negatif). Perlakuan yang paling berbeda nyata adalah P2 dan P6 yang menunjukan bahwa P2 atau pemberian ekstrak tanaman putri malu konsentrasi $20 \%$ sangat efektif dalam menurunkan glukosa darah. P5 menunjukan penurunan kadar glukosa darah yang signifikan karena glibenklamid adalah obat hipoglikemik oral golongan sulfonilurea yang mekanisme kerjanya merangsang sekresi insulin di kelenjar pankreas (Nugrahani, 2012). Menurut Nugroho (2006) penurunan kadar glukosa darah dapat melalui jalan lain dengan memperbaiki kerusakan akibat mekanisme aloksan dimana mengganggu homeostatis intraseluler menyebabkan depolarisasi sel $\beta$ pankreas dan membuka kanal kalsium sehingga terjadi gangguan sensitivitas insulin.

Penentuan adanya perbedaan yang signifikan antar keenam perlakuan dapat diketahui dengan melakukan uji statistik menggunakan analisis varians (ANAVA).

Tabel 3. Hasil uji ANOVA untuk penurunan

\begin{tabular}{|c|c|c|c|c|c|}
\hline \multicolumn{6}{|c|}{ kadar glukosa } \\
\hline & $\begin{array}{l}\text { Sum of } \\
\text { Squares }\end{array}$ & $\mathrm{df}$ & $\begin{array}{l}\text { Mean } \\
\text { Square }\end{array}$ & $\mathrm{F}$ & Sig. \\
\hline $\begin{array}{l}\text { Between } \\
\text { Groups }\end{array}$ & 6173.111 & 5 & 1234.622 & 4.653 & .014 \\
\hline Within Groups & 3184.000 & 12 & 265.333 & & \\
\hline Total & 9357.111 & 17 & & & \\
\hline
\end{tabular}

Pada Tabel 3 menunjukan bahwa antar perlakuan mempunyai nilai signifikan $0,014<$ $\alpha=0,05$. Hai ini berarti terdapat penurunan glukosa darah yang bermakna diantara keenam kelompok perlakuan. Hasil uji anava didapatkan Fhitung $=4,653$ lebih besar dibanding Ftabel $5 \%=3,11$. Hal ini menunjukan terjadi perbedaan signifikan antar kelompok. Hal ini menandakan keenam kelompok memiliki efektivitas cukup berbeda dalam menurunkan kadar glukosa darah. Setelah uji Anava dilanjutkan dengan uji Duncan. Uji ini untuk mengetahui pada perlakuan mana yang memiliki perbedaan yang bermakna dalam menentukan konsentrasi yang paling efektif dalam menurunkan kadar glukosa darah pada mencit.

Tabel 4. Hasil uji Duncan untuk penurunan

\begin{tabular}{lccr}
\multicolumn{4}{c}{ kadar glukosa } \\
\hline \multirow{4}{*}{ Perlakuan } & Subset for alpha $=$ \\
& 1 & 2 & 1 \\
\hline P6 & 3 & 12.0000 \\
P4 & 3 & 24.3333 & \\
P1 & 3 & 31.6667 & 31.6667 \\
P2 & 3 & & 55.3333 \\
P5 & 3 & & 58.0000 \\
P3 & 3 & & 60.0000 \\
Sig. & & $\mathbf{1 8 4}$ & .071 \\
\hline
\end{tabular}

Tabel 4 hasil perhitungan uji statistik uji Duncan dengan taraf signifikan 5\% menunjukan pemberian ekstrak 40\% (P4) dan P6 (kontrol negatif) yaitu perlakuan tanpa ekstrak menunjukan perbedaan nyata jika dibandingkan dengan perlakuan lainnya. Pada perlakuan pemberian ekstrak tanaman putri malu 20\% dan 30\% (P2 dan P3) berbeda signifikan dengan kontrol negatif namun tidak memiliki perbedaan signifikan dengan obat glibenklamid (P5) yaitu pada P2 sudah memberikan efek yang hampir sama dengan pemberian obat glibenklamid sedangkan pada P3 memberikan efek lebih besar dibandingkan kontrol positif. Jadi konsentrasi yang paling efektif dalam menurunkan kadar glukosa darah adalah pemberian konsentrasi ekstrak tanaman putri malu 20\% (P2). Disini terlihat bahwa konsentrasi $40 \%$ yang digunakan, efeknya justru lebih kecil dari pada konsentrasi yang kecil. Hal ini sering dijumpai juga pada aktivitas ekstrak yang merupakan campuran multikomponen. Efek dari komponen-komponen tersebut dapat 
saling sinergis, adiktif maupun antagagonis, sehingga kemungkinan pada konsentrasi yang lebih besar ekstrak tanaman putri malu semakin mengalami kerusakan jaringan penghasil insulin. Untuk itu perlu dikaji lebih lanjut efek toksik dari ekstrak tanaman putri malu dalam kaitannya dengan penggunaannya sebagai obat antidiabetes (Yulianah, dkk., 2001). Keefektifan ekstrak tanaman putri malu dalam menurunkan kadar glukosa darah dipengaruhi oleh senyawa bioaktif yang terkandung dalam ekstrak tanaman putri malu yaitu Flavanoid, alkaloid dan tanin.

\section{Kesimpulan}

Ekstrak tanaman putri malu (Mimosa pudica Linn) dapat menurunkan kadar glukosa darah pada mencit dengan konsentrasi yang paling efektif dalam menurunkan kadar glukosa darah mencit (Mus musculus) sebesar 20\% (b/v) dengan $\alpha=0,05$.

\section{Ucapan Terima Kasih}

Penulis mengucapkan terima kasih kepada laboran Laboratorium Kimia FKIP Universitas Tadulako dan semua pihak yang telah banyak membantu penulis dalam menyelesaikan penelitian ini.

\section{Referensi}

Arjadi, F., \& Susatyo, P. (2010). Islet of langerhans regeneration in diabetc white rats (rattus norvegicu) after giving decocted pulp of mahkota dewa (phaleria macrocarp (scheff.) boerl). Jurnal of Medical Faculty Jenderal Soedirman University, 2(2), 117126.

Azmi, L., Singh, M. K., \& Akhtar, A. K. (2011). Pharmacological and biological overview on mimosa pudica Linn. International Journal of Pharmacy \& Life Sciences, 2(11), 12261234.

Evasuciany, E., Delima, E. R., \& Boen, R. (2010). The effect of morinda citrifolia L. ethanol extract on blood in alloxan induced male mice swiss webster strain. Jurnal Medika Planta, 1(1), 87-92.

Fauziah, Nika.N, Putri, \& Firdu. (2014). The effect of curry leaves (murayya koenigii L.) on blood glucose levels in alloxan diabetic mice (mus musculus). Jurnal Natural,
14(1), 23-29.

Hussain, S. A., \& Marouf, B. H. (2013). Flavonoids as alternatives in treatment of type 2 diabetes mellitus. Academia Journal of Medicinal Plants, 1(2), 031-036.

Kirwanto, A. (2014). Upaya pengendalian kadar gula darah dengan menggunakan modifikasi diet pare pada penderita diabetes mellitus di klinik sehat migunani klaten. Jurnal Terpadu Ilmu Kesehatan, 3(2), 106214.

Novrial, D., Sulistio, H., \& Setiawati. (2012). Perbandingan efek antidiabetik madu,glibenklamid, metformin dan kombinasi pada tikus yang diinduksi streptozotocin. Prosiding Seminar Nasional Kesehatan Jurusan Kesehatan Masyarakat FKIK UNSOED.

Nugrahani, S. S. (2012). Analisis perbandingan efektifitas ekstrak akar, batang, dan daun herba meniran (phyllanthus ninuri) dalam menurunkan kadar glukosa darah mencit. Skripsi. Universitas Negeri Semarang, tidak diterbitkan.

Nugroho, A. E. (2006). Hewan percobaan diabetes melitus: pathology mekanisme aksi diabetogenik. Biodiversitas, 7(4), 381-389.

Nursyiah. (2013). Studi eskriptif tanaman obat tradisional yang digunakan orangtua untuk kesehatan anak usia dini di gugus melati kecamatan kalikajar kabupaten Wonosobo. Skripsi. Universitas Negeri Semarang, Tidak diterbitkan

Nurulita, Y., Dhanutirto, H., Andreanus., \& Soemardji. (2008). Penapisan aktivitas dan senyawa antidiabetes ekstrak air daun dandang gendis (clinacanthus nutans). Jurnal Natur Indonesia, 10(2), 98-103.

Purwatresna, E. (2012). Aktivitas antidiabetes ekstrak air dan etanol daun sirsak secara in vitro melalui inhibisi enzim a-glukosidase. Skripsi. Institut Pertanian Bogor, Tidak diterbitkan.

Putri, E. P. K. (2013). Analisis kualitatif bioaktif pada ekstrak daun alpukat (persea americana mill.) dan uji praklinis dalam menrunkan kadar glukosa darah pada mencit (mus muculus). Skripsi. Universitas Tadulako 
Palu, Tidak diterbitkan.

Radiansah, R. (2013). Ekstrak daun kelor (moringa oleifera) sebagai alternatif untuk menurunkan kadar gula darah pada mencit. Skripsi. Universitas Tadulako Palu, tidak diterbitkan.

Ranakusuma, B. (1987). Diabetes mellitus tipe sirosis hepatis. Jakarta: UI PRESS.

Salam, A. A. (2011). Uji efektifitas daun lere (Ipomea Pes-caprae (L) Roth Br.) sebagai alternatif untuk menurunkan kadar glukosa darah kelinci (Oryctologus Cuniculus). Skripsi. Universitas Tadulako Palu, Tidak diterbitkan.

Setiawati, W., Murtiningsih, R., Gunaeni, N., \& Rubiati. (2008). Tumbuhan bahan pestisida nabati dan cara pembuatannya untuk pengendalian organisme pengganggu tumbuhan (OPT). Bandung: Balai Penelitian Tanaman Sayuran.
Sukandar, D., Sumarlin, L. O., Zahroh, H., \& Amelia, E. R. (2012). Uji aktivitas antidiabetes fraksi etil asetat daun pandan wangi (p. amaryllifolius roxb.) dengan metode $\alpha$-glukosidase. Jurnal Valensi, 2(5), 534-540.

Taufiqurrohman. (2015). Indonesian bay leaves as antidiabetic for type 2 diabetes mellitus. Jurnal Majority, 4(3), 101-107.

Winarsi, H., Sasongko, N. D., Purwanto, A., \& Nuraeni, I. (2014). Effect of cardamom leaves extract as antidiabetic, weight lost and hypocholesterolemic to alloxan-induced sprague dawley diabetic rats. International Food Research Journal, 21(6), 2253-2261.

Yulianah, E., Sukarsono, \& Fitri, M. A. (2001). Aktivitas antidiabetika ekstrak etanol herba sambiloto (Andrographis paniculata Nees (Acanthaceae). Jurnal Matematika dan Sains, 6(1), 13-20. 